\title{
Choline Sulfate Ester as Sulfur Source for the Growth of Fungi
}

\author{
by Michiko ITAHASH* \\ 板橋美智子*: 菌類の発育のための硫黄源としてのコリン硫酸エステル
}

Received February 26, 1959

The modes of metabolism of sulfur cmpounds in organisms are actually different from one to another. While, many plants and micro-organisms can grow up by taking only inorganic sulfate as sulfur source, animals must take S-containing amino acids for growth and maintenance. Inorganic sulfate taken up by micro-organisms and higher plants is changed into sulfate esters or other organic S-containing compounds. In the course of the reaction forming S-containing amino acids from inorganic sulfate, reduction of sulfate and combination of an inorganic sulfur compound with an organic compound should take place successively, although the whole reaction aspect has not yet been elucidated.

Choline sulfate ester $\left(\mathrm{CH}_{3}\right)_{3} \mathrm{~N}^{+} \mathrm{CH}_{2} \mathrm{CH}_{2} \mathrm{OSO}_{3}-$ which was inferred by Raistrick and Vincent ${ }^{1)}$ to be an intermediate substance of sulfur metabolism, has been isolated by Woolley and Peterson ${ }^{2)}$ from Aspergillus sydowi.

In the previous paper( $\left.{ }^{34}\right)^{5}$ ) it has been reported by F. Egami and the present author that choline sulfate ester is effective for the growth of Aspergillus oryzae as a source of sulfur. They have also recognized the production of choline sulfate ester from inorganic sulfate in the mycelium of Aspergillus oryzae by using $\mathrm{S}^{35}$ as a tracer element. J. de Flines ${ }^{6}$ ) also identified choline sulfate ester in the mycelial extract from Penicillium chrysogenum.

The present paper deals with the utilization of choline sulfate ester as source of sulfur in several kinds of fungi.

\section{Experiments and Results}

The synthetic media used are as follows:

\section{Solutions}

Basal Medium-1 (BM No. 1): One liter containing; $50 \mathrm{~g}$. of sucrose, $10 \mathrm{~g}$. of $\mathrm{NH}_{4} \mathrm{NO}_{3}, 0.2 \mathrm{~g}$. of $\mathrm{KH}_{2} \mathrm{PO}_{4}$ and $0.01 \mathrm{~g}$. of $\mathrm{FeCl}_{3}(\mathrm{pH} 5.5)$.

Basal Medium-2 (BM No. 2): One liter containing; $80 \mathrm{~g}$. of sucrose, $2 \mathrm{~g}$. of

\footnotetext{
* Aichi Gakugei University, Higashi-ku, Nagoya, Japan. 愛知学芸大学名古屋分校
} 
$\left(\mathrm{NH}_{4}\right)_{2} \mathrm{HPO}_{4}, 2 \mathrm{~g}$. of $\mathrm{KH}_{2} \mathrm{PO}_{4}, 0.2 \mathrm{~g}$. of $\mathrm{CaCl}_{2}$ and $0.01 \mathrm{~g}$. of $\mathrm{FeCl}_{3}(\mathrm{pH} 6.8)$.

Basal Medium-3 (BM No. 3): One liter containing; $40 \mathrm{~g}$. of glucose, $4 \mathrm{~g}$. of $\mathrm{K}_{2} \mathrm{HPO}_{4}, 4 \mathrm{~g}$. of asparagin, $2 \mathrm{~g}$. of $\left(\mathrm{NH}_{4}\right)_{2} \mathrm{HPO}_{4}, 0.2 \mathrm{~g}$. of $\mathrm{CaCl}_{2}$ and $0.01 \mathrm{~g}$. of $\mathrm{FeCl}_{3}$ ( $\mathrm{pH}$ 6.6).

Choline Sulfate Ester Solution: One liter contains $18.3 \mathrm{~g}$. of choline sulfate ester $(\mathrm{M} / 10)$ and $20.3 \mathrm{~g}$. of $\mathrm{MgCl}_{2} \cdot 6 \mathrm{H}_{2} \mathrm{O}(\mathrm{M} / 10)$.

Magnesium Sulfate Solution: One liter contains $24.6 \mathrm{~g}$. of $\mathrm{MgSO}_{4} \cdot 7 \mathrm{H}_{2} \mathrm{O}(\mathrm{M} / 10)$.

The solutions are sterilized by steaming for $30 \mathrm{~min}$. on three succesive days and stored at room temperature until use.

\section{Culture Medium}

Each medium was prepared by mixing the above-mentioned stock-solutions in the following proportions:

Medium-1 (M No.1):

M. No. 1-CS

[BM No. 1 ....................... $90 \mathrm{ml}$.

Choline sulfate ester solution $\ldots \ldots \ldots \ldots \ldots \ldots \ldots \ldots . \ldots \ldots$ ml. $(\mathrm{M} / 100)$

M. No. $1-\mathrm{SO}_{4}{ }^{\prime \prime}$

[BM No. 1 ......................... $90 \mathrm{ml}$.

Magnesium sulfate solution .................... $10 \mathrm{ml} .(\mathrm{M} / 100)$

Medium-2 (M. No. 2):

M. No. 2-CS

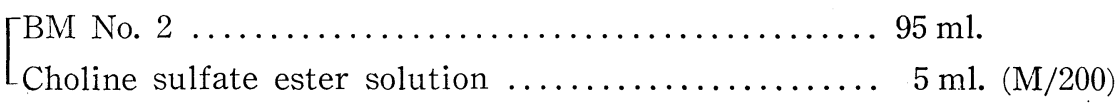

M. No. $2 / \mathrm{SO}_{4}{ }^{\prime \prime}$

BM No. 2 .......................... $95 \mathrm{ml}$.

Magnesium sulfate solution ................ $5 \mathrm{ml} .(\mathrm{M} / 200)$

Medium-3 (M. No.3):

M. No. 3-CS

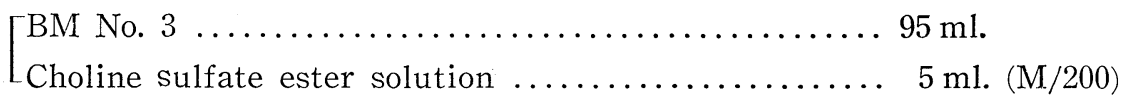

M. No. $3-\mathrm{SO}_{4}{ }^{\prime \prime}$

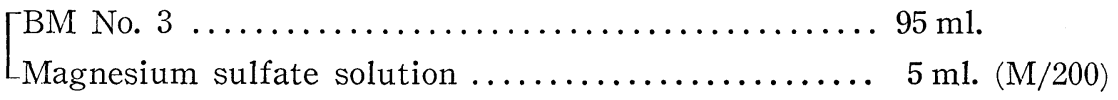

The medium $(50 \mathrm{ml}$.) was accurately measured into a series of $300 \mathrm{ml}$. conical flasks plugged with cotton, and sterilized by heating in flowing steam for $30 \mathrm{~min}$. on three successive days. The flasks were then inoculated with a pure culture of the fungus to be tested, and incubated at $28^{\circ}$ for a requisite period of days. The mycelium from each species was separated quantitatively by filtration on a 
Buchner funnel, and was thoroughly washed with warm water. The mycelium was then dried to constant weight in vacuo and weighed. The filtrate and the washings were made up to a total volume of $50 \mathrm{ml}$., and analyzed by the methods described below.

Ten ml. of the culture-filtrate were accurately measured into a beaker, and acidified with $2 \mathrm{ml}$. of $\mathrm{HCI}(6 \mathrm{~N})$; and $1 \mathrm{ml}$. of $\mathrm{BaCl}_{2}(10 \%)$ and $10 \mathrm{ml}$. of $\mathrm{H}_{2} \mathrm{O}$ were successively added. The vessel covered by a watch glass to lessen evaporation, was gently boiled for $20 \mathrm{~min}$. In the course of this treatement, choline sulfate ester was quantitatively hydrolyzed to produce a precipitate of $\mathrm{BaSO}_{4}$, which was weighed as usual.

Table I shows the results obtained with six species of moulds belonging to Aspergillales.

Each flask containing $50 \mathrm{ml}$. of M. No. 1-CS (or M. No. 1-SO ${ }_{4}^{\prime \prime}$ ) with a sulfate content equivalent to $16 \mathrm{mg}$. sulfur/flask, was inoculated with a culture of the mould species to be tested. Figures in Columns 5 and 9 , indicate, in weight of $\mathrm{BaSO}_{4}$, the quantities of organic and inorganic sulfate utilized by the mould during the incubation period (i.e., the difference between the amount of sulfate originally present in the medium and that remaining in the residual culture medium).

The moulds used in this set of experiments included three species of Aspergillus, one species of Monascus and two species of Penicillium. The experimental results show that all the froms belonging to these genera readily utilize choline sulfate ester as sulfur source, giving a better growth as compared with that obtained with inorganic sulfate as sulfar source; the only exception being the case of Penicillium notatum. From the fact that in these moulds, inorganic sulfate ion was not detected in the residual culture medium when choline sulfate ester was used as sulfur source, it will be concluded that choline sulfate ester must have been absorbed as

Table I

\begin{tabular}{|c|c|c|c|c|c|c|c|c|c|}
\hline \multirow[b]{2}{*}{ Organism } & \multirow{2}{*}{ 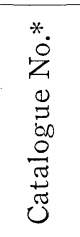 } & \multirow{2}{*}{ 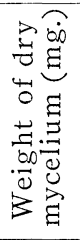 } & \multirow{2}{*}{ 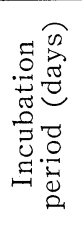 } & \multicolumn{2}{|c|}{$\begin{array}{l}\text { Utilization of } \\
\text { choline sulfate }\end{array}$} & \multirow{2}{*}{ 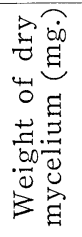 } & \multirow{2}{*}{ 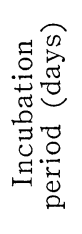 } & \multicolumn{2}{|c|}{$\begin{array}{l}\text { Utilization of } \\
\text { inorganic sulfate }\end{array}$} \\
\hline & & & & $\begin{array}{c}\text { Sulfate } \\
\text { utilized } \\
\text { (BaSO } \mathrm{mg}_{4} / \\
\text { flask) }\end{array}$ & $\%$ & & & $\begin{array}{c}\text { Sulfate } \\
\text { utilized } \\
\text { (BaSO }{ }_{4} \mathrm{mg} \cdot / \\
\text { flask) }\end{array}$ & $\%$ \\
\hline Aspergillus niger & 4407 & 375 & 9 & 12 & 10.3 & 370 & 9 & 5 & 4.3 \\
\hline Asp. sydowi & 4402 & 895 & 9 & 100 & 86.0 & 795 & 9 & 45 & 38.8 \\
\hline Asp. oryza $e^{* *}$ & & 670 & 6 & 37 & 31.9 & 660 & 6 & 25 & 21.5 \\
\hline Penicillium notatum & 4640 & 510 & 11 & 20 & 17.2 & 650 & 11 & 30 & 25.8 \\
\hline P. chrysogenum & 4626 & 690 & 11 & 25 & 21.5 & 550 & 11 & 36 & 31.0 \\
\hline Monascus purpureus & 4513 & 632 & 14 & 12 & 10.3 & 550 & 14 & 9 & 7.7 \\
\hline
\end{tabular}

* Obtained from the Institute for Fermentation, Osaka. (Table I-IV)

** Obtained from the Faculty of Science, Nagoya University.

Initial amount of choline sulfate (or inorganic sulfate) in each flask; $116.5 \mathrm{mg}$. (on $\mathrm{BaSO}_{4}$ basis) 
such, i. e., without previous hydrolysis.

Table II shows the results obtained with two species of Neurospora belonging to Pyrenomycetes and several other species belonging to Fungi Imperfecti. Each flask containing $50 \mathrm{ml}$. of M. No. 2-CS (or M. No. 2- $\mathrm{SO}_{4}{ }^{\prime \prime}$ ) with a sulfate content equivalent to $8 \mathrm{mg}$. sulfur/flask, was inoculated. This group also readily utilized. choline sulfate ester as a sulfur source and showed again a growth similar to that observed with inorganic sulfate as sulfur source. For every mould examined, except for Alternaria tenuis, no inorganic sulfate was detected in the residual medium which had initially contained choline sulfate ester as sulfur source. In the case of Alternaria tenuis, $39.2 \%$ of choline sulfate ester and $26.8 \%$ inorganic sulfate ion found in the residual medium. This probably means that $34 \%$ of choline sulfate ester was absorbed and $26.8 \%$ of the remaining (66\%) was hydrolyzed by the mould.

Since it seemed very likely that Alternaria tenuis would utilize as sulfur source the sulfate ions liberated through hydrolysis of choline sulfate ester, another experiment was made to check this point. A number of conical flasks (500 ml.) containing $50 \mathrm{ml}$. of M. No. 2-CS were inoculated with Alternaria tenuis and, after incubating at $28^{\circ}$ on a shaker for five days, the sulfate remaining in the medium was determined. In this case, contrary to expectation, no inorganic sulfate ion was found in the residual medium, although this was a consumption of $15 \%$ of the choline sulfate ester added.

Table II

\begin{tabular}{|c|c|c|c|c|c|c|c|c|c|}
\hline \multirow[b]{2}{*}{ Organism } & \multirow{2}{*}{$\begin{array}{l}* \\
0 \\
Z \\
0 \\
0 \\
0 \\
0 \\
\frac{0}{\pi} \\
\stackrel{0}{\pi} \\
0\end{array}$} & \multirow{2}{*}{ 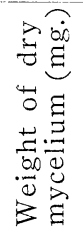 } & \multirow{2}{*}{ 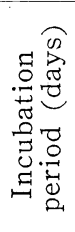 } & \multicolumn{2}{|c|}{$\begin{array}{l}\text { Utilization of } \\
\text { choline sulfate }\end{array}$} & \multirow{2}{*}{ 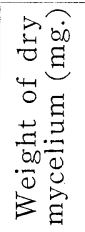 } & \multirow{2}{*}{ 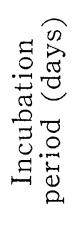 } & \multicolumn{2}{|c|}{$\begin{array}{l}\text { Utilization of } \\
\text { inorganic sulfate }\end{array}$} \\
\hline & & & & $\begin{array}{c}\text { Sulfate } \\
\text { utilized } \\
\left(\mathrm{BaSO}_{4} \mathrm{mg} \cdot /\right. \\
\text { flask })\end{array}$ & $\%$ & & & $\begin{array}{c}\text { Sulflate } \\
\text { utilized } \\
\left(\text { BaSO }_{4} \mathrm{mg} . /\right. \\
\text { flask })\end{array}$ & $\%$ \\
\hline Neur ospora crassa & 6178 & 93 & 8 & 3.2 & 5.5 & 117 & 8 & 7.1 & 12.2 \\
\hline$N$. sitophila & 6070 & 298 & 8 & 6.2 & 10.7 & 353 & 8 & 12.1 & 20.9 \\
\hline Alternaria tenuis & 4026 & 347 & 9 & 19.7 & 34.0 & 750 & 9 & 19.3 & 33.3 \\
\hline Botrytis cinerea & 5964 & 934 & 9 & 17.4 & 30.0 & 656 & 9 & 17.1 & 29.5 \\
\hline Fusarium solani & 5893 & 420 & 8 & 8.1 & 13.9 & 386 & 8 & 8.2 & 14.1 \\
\hline Oospora lactis & 4597 & 528 & 8 & 6.6 & 11.4 & 390 & 8 & 6.4 & 11.0 \\
\hline Pullularia pullulans & 4464 & 725 & 8 & 14.7 & 25.4 & 368 & 8 & 5.8 & 10.0 \\
\hline Trichothecium roseum & 6157 & 195 & 9 & 6.2 & 10.7 & 250 & 9 & 12.6 & 21,8 \\
\hline
\end{tabular}

Initial amount of choline sulfate (or inorganic sulfate) in each flask; $58.2 \mathrm{mg}$. (on $\mathrm{BaSO}_{4}$ basis)

Table III shows the results obtained for six species of yeasts. Each flask. containing $50 \mathrm{ml}$. of M. No. 2-CS (or M. No. 2- $\mathrm{SO}_{4}{ }^{\prime \prime}$ ) with a sulfate content equivalent to $8 \mathrm{mg}$. sulfur/flask, was inoculated from a culture of yeast to be tested. All. the organisms of this group, with only one exception, did not practically absorb. 
choline sulfate ester and, moreover, they often showed certain sign of incomplete growth as compared with that observed in normal medium. Hansenula anomala, however, absorbed $20 \%$ of the choline sulfate ester given as sulfur source and showed greater increase in dry weight than that obtained in normal medium containing inorganic sulfate (M. No. $2-\mathrm{SO}_{4}{ }^{\prime \prime}$ ).

Table III

\begin{tabular}{|c|c|c|c|c|c|c|c|c|c|}
\hline \multirow[b]{2}{*}{ Organism } & \multirow{2}{*}{$\begin{array}{l}* \\
0 \\
Z \\
0 \\
0 \\
00 \\
0 \\
\frac{0}{0} \\
\stackrel{0}{0}\end{array}$} & \multirow{2}{*}{ 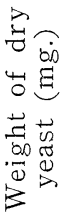 } & \multirow{2}{*}{ 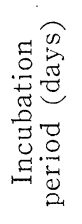 } & \multicolumn{2}{|c|}{$\begin{array}{l}\text { Utilization of } \\
\text { choline sulfate }\end{array}$} & \multirow{2}{*}{ 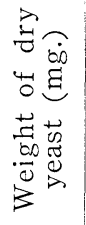 } & \multirow{2}{*}{ 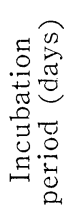 } & \multicolumn{2}{|c|}{$\begin{array}{c}\text { Utilization of } \\
\text { inorganic sulfate }\end{array}$} \\
\hline & & & & $\begin{array}{c}\text { Sulfate } \\
\text { utilized } \\
\left(\begin{array}{c}\text { BaSO } \\
\text { mg./ } \\
\text { flask })\end{array}\right.\end{array}$ & $\%$ & & & $\begin{array}{c}\text { Sulfate } \\
\text { utilized } \\
\left(\mathrm{BaSO}_{4} \mathrm{mg} . /\right. \\
\text { flask })\end{array}$ & $\%$ \\
\hline $\begin{array}{l}\text { Saccharomyces } \\
\text { cerevisiae }\end{array}$ & 0209 & 92 & 4 & 0.8 & negligibie & 116 & 4 & 4.4 & 7.6 \\
\hline $\begin{array}{l}\text { Sarcharomyces } \\
\text { Strain XII }\end{array}$ & 2113 & 140 & 4 & 0.6 & " & 146 & 4 & 7.4 & 12.7 \\
\hline Hansenula anomala & 4540 & 218 & 5 & 11.3 & 19.5 & 154 & 5 & 5.6 & 9.7 \\
\hline $\begin{array}{l}\text { Schizosaccharomyces } \\
\text { octosporus }\end{array}$ & 0353 & 8 & 5 & 0.9 & negligible & 42 & 5 & 5.8 & 10.0 \\
\hline $\begin{array}{l}\text { Zygosaccharomyces } \\
\text { marxianus }\end{array}$ & 0219 & 55 & 5 & 0.7 & " & 96 & 5 & 5.4 & 9.3 \\
\hline $\begin{array}{l}\text { Candida tropicalis } \\
\text { var. japonica }\end{array}$ & 0618 & 145 & 4 & 1.0 & it & 150 & 4 & 4.6 & 7.9 \\
\hline
\end{tabular}

Initial amount of choline sulfate (or inorganic sulfate) in each flask; $58.2 \mathrm{mg}$. (on $\mathrm{BaSO}_{4}$ basis)

Table IV contains the results obtained for five species of moulds belonging to Phycomycetes. Each flask containing $50 \mathrm{ml}$. of M. No. 2-CS (or M. No. 2- $\mathrm{SO}_{4}^{\prime \prime}$ ) with suifate content equivalent to $8 \mathrm{mg}$. sulfur/flask, was inoculated and incubated for a requisite period of days. Of the members of this group, only Rhizopus oryzae utilized choline sulfate ester as sulfur source and showed favorable growth. Rhizopus nigricans and Mucor mucedo did not utilize the ester and the growth in CS-medium insignificant. Phycomyces and Absidia failed to grow even in normal medium.

Table IV

\begin{tabular}{|c|c|c|c|c|c|c|c|c|c|}
\hline \multirow[b]{2}{*}{ Organism } & \multirow{2}{*}{ 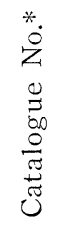 } & \multirow{2}{*}{ 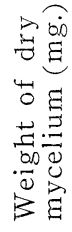 } & \multirow{2}{*}{ 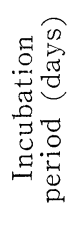 } & \multicolumn{2}{|c|}{$\begin{array}{l}\text { Utilization of } \\
\text { choline sulfate }\end{array}$} & \multirow{2}{*}{ 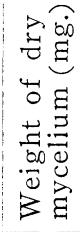 } & \multirow{2}{*}{ 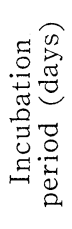 } & \multicolumn{2}{|c|}{$\begin{array}{l}\text { Utilization of } \\
\text { inorganic sulfate }\end{array}$} \\
\hline & & & & $\begin{array}{c}\text { Sulfate } \\
\text { utilized } \\
\left(\mathrm{BaSO}_{4} \mathrm{mg} \cdot /\right. \\
\text { flask })\end{array}$ & $\%$ & & & $\begin{array}{c}\text { Sulfate } \\
\text { utilized } \\
\left(\mathrm{BaSO}_{4} \mathrm{mg} . /\right. \\
\text { flask) }\end{array}$ & $\%$ \\
\hline Rhizopus nigricans & 5411 & 60 & 8 & 0.5 & negligible & 207 & 5 & 4.7 & 8.1 \\
\hline Rhizopus oryzae & 4746 & 300 & 9 & 5.5 & 9.5 & 337 & 9 & 9.2 & 15.8 \\
\hline Mucor mucedo & 5776 & 58 & 8 & 0.6 & negligible & 134 & 8 & 4.5 & 7.8 \\
\hline Phycomyces nitens & 5694 & 90 & 9 & 0.4 & $" \prime$ & 98 & 9 & 4. 2 & 7.2 \\
\hline Absidia glauca & 4002 & 45 & 9 & 0.5 & $/ /$ & 56 & 9 & 3.0 & 5.2 \\
\hline
\end{tabular}

Initial amount of choline sulfate (or inorganic sulfate) in each flask; $58.2 \mathrm{mg}$. (on $\mathrm{BaSO}_{4}$ basis) 
Table $\mathrm{V}$ shows the results obtained for four species of Basidiomycetes. Each flask containing $50 \mathrm{ml}$. of M. No. 3-CS (or M. No. 3-SO ${ }_{4}^{\prime \prime}$ ) with sulfate content equivalent to $8 \mathrm{mg}$. sulfur/flask, was inoculated. None of this group ever utilized choline sulfate ester.

Table V

\begin{tabular}{|c|c|c|c|c|c|c|c|c|}
\hline \multirow[b]{2}{*}{ Organism*** } & \multirow{2}{*}{ 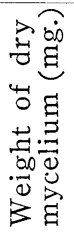 } & \multirow{2}{*}{ 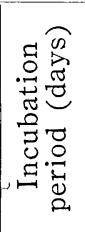 } & \multicolumn{2}{|c|}{$\begin{array}{l}\text { Utilization of } \\
\text { choline sulfate }\end{array}$} & \multirow{2}{*}{ 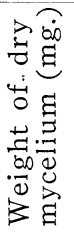 } & \multirow{2}{*}{ 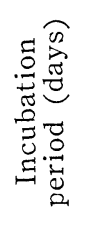 } & \multicolumn{2}{|c|}{$\begin{array}{l}\text { Utilizatlon of } \\
\text { inorganic sulfate }\end{array}$} \\
\hline & & & $\begin{array}{c}\text { Sulfate } \\
\text { utilized } \\
\left(\begin{array}{c}\mathrm{BaSO}_{4} \mathrm{mg} \cdot / \\
\text { flask })\end{array}\right.\end{array}$ & $\%$ & & & $\begin{array}{c}\text { Sulfate } \\
\text { utilized } \\
\left(\begin{array}{c}\mathrm{BaSO}_{4} \mathrm{mg} \cdot / \\
\text { flask })\end{array}\right.\end{array}$ & $\%$ \\
\hline Polystictus hirsutus & 140 & 13 & 0.5 & negligible & 115 & 13 & 7.2 & 12.4 \\
\hline Fomes fomentarius & 72 & 13 & 0.4 & " & 50 & 13 & 8.3 & 14.4 \\
\hline Schizophyllum commune & 56 & 13 & 0.7 & " & 36 & 13 & 4.7 & 8.0 \\
\hline Pleurotus japonicus Kawam. & 83 & 13 & 0.5 & $" \prime$ & 65 & 13 & 9.2 & 15.8 \\
\hline
\end{tabular}

*** Obtained from the Faculty of Agriculture, Gifu University.

Initial amount of choline sulfate (or inorganic sulfate) in each flask; $58.2 \mathrm{mg}$. (on $\mathrm{BaSO}_{4}$ basis)

\section{Discussion $^{9)}$}

As is generally known, most micro-organisms are capable of utilizing inorganic sulfate as sulfur source. Cowie et $a l^{7}{ }^{7)}$ considered that, for the case of Escherichia coli, $\mathrm{SO}_{4}$ " absorbed by the organism is reduced to $\mathrm{SO}_{3}$ ", prior to the ensuing conversion into organic S-compound. The reaction scheme assumed by these authors is as follows :

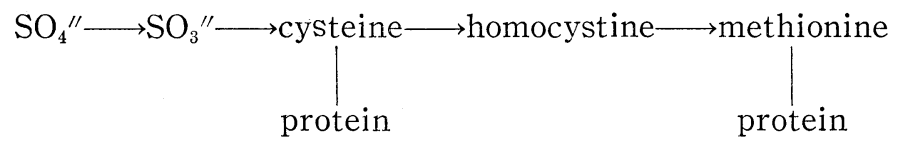

In the present study, it was revealed that among twenty-nine fungal organisms examined, six belonging to Aspergillales, two belonging Pyrenomycetes together with six Fungi Imperfecti are capable of utilizing choline sulfate ester as sulfur source. With other organisms, including five species of yeasts, four Phycomycetes, and four Basidiomycetes, the results were negative in this respect.

The above-mentioned positive results suggest a possibility that choline sulfate ester represents a normal intermediary of sulfur assimilation in these organisms, especially when we remember the fact that the substance has been identified as a normal constituent of certain fungal organisms ${ }^{\left.25^{5} 6\right)}$. Although a sufficient body of evidence has not yet been obtained concerning the precise mechanisms of the process involved, the above-described finding with Alternaria tenuis, will be of special interest in this connetion. In one experiment with this mould, a certain quantity of sulfate jon arising most plausibly from partial hydrolysis of choline sulfate ester, was detected in the residual culture medium, while the result was negative 
in this respect in another experiment performed with the same organism. The discrepancy between these two results may be due to the differences in the relative levels of activity of the organism in hydrolyzing the ester and absorbing sulfate ions, as influenced by cultural conditions. In fact, the former experiment was carried out with an ordinary flask culture, while the latter was done with a shaking culture of the same organism. A detailed study pertaining to this point is being: carried out.

Most of the yeast species examind in this study, including two Saccharomyces, one each of Schizosaccharomyces, Zygosaccharomyces and Candida, showed no utilization of choline sulfate ester in the course of metabolism (see Table III). Accordingly, choline sulfate ester does not appear to be an intermediate substace of metabolism for the sulfur assimilation reaction in these organisms. However, Hansenula anomala which is taxonomically closely related to Saccharomyces ${ }^{8}$, not only absorbed the organic sulfate ester, but showed much better growth compared with the case in which inorganic sulfate was given as sulfur source. This fact suggests that there must be some yeasts in which choline sulfate ester may be an intermediary metabolite of sulfur assimilation.

Table IV contains the results obtained for five species belonging to Phycomycetes. For Mucor mucedo, Phycomyces nitens and Absidia glauca did not utilize choline sulfate ester as sulfur source but, in Rhizopus oryzae about $9 \%$ of choline sulfate added was consumed with a fairly abundant growth. Rhizopus nigricans, on the other hand did not utilize the organic sulfate ester.

It may be inferred from these findings that the capacity for utilizing choline: sulfate ester is not limited to the class of Ascomycetes, in which the substance has been discovered as a normal constituent, but is of more or less common occurrence also among Phycomycetes and Fungi Imperfecti, in which the production of the substance has not yet been reported.

It may be of some interest to note in this connection that all of the four higher fungi (Basidiomycetes) examined in the present study showed more favorable growth in the presence of choline sulfate ester (M. No. 3-CS) than in the sulfate medium (M. No. 3- $\mathrm{SO}_{4}{ }^{\prime \prime}$ ), although there was no appreciable consumption of the added choline sulfate ester during the incubation period. This fact seems to indicate a possibility that choline sulfate ester may be playing the role of a growth facter in Basidiomycetes, although the final decision must await further investigation.

\section{Summary}

The utilizability of choline sulfate ester as sulfur source was examined in twenty-nine fungi belonging to the following Classes: Phycomycetes, Ascomycetes, Basidiomycetes and Fungi Imperfecti.

Choline sulfate ester was found to be utilized as sulfur source in Aspergillales, 
Pyrenomycetes and Fungi Imperfecti. In some cultures with Alternaria tenuis an accumulation of certain amounts of sulfate ions in the residual culture medium was detected.

No utilization was revealed in yeasts (Saccharomyces, Schizosaccharomyces, Zygosaccharomyces, Candida), a single exception being Hansenula anomala which consumed the substance to give a fairly abundant growth in its presence in the culture medium.

Choline sulfate ester was not utilized in the Phycomycetes species studied (Rhizopus nigricans, Mucor, Phycomyces, Absidia), with the single exception of Rhizopus oryzae, which utilized the substance to show a fairly good growth in its presence.

All the Basidiomycetes species examined did dot appreciably consume choline sulfate ester but all of them showed enhanced growth in the presence of this substance.

In conclusion the author wishes to express her sincere appreciations to Prof. F. Egami (University of Tokyo) and Prof. T. Mori (Nagoya University) for their kind guidance throughout the investigation and for their kindness in reading the original manuscript.

\section{References}

1) Raistrick, H. and Vincent, J. M., Biochem. J. 43 : 90 (1948). 2) Woolley, D. W. and Peterson, W. H., J. Biol. Chem. 122: 213 (1937). 3) Itahashi, M. and Egami, F., Bot. Mag. Tokyo 63: 283 (1950). 4) Egami, F. and Itahashi, M., Med. Biol. $19: 292$ (1951). 5) Itahashi, M., Bull. Aichi Gakugei Univ. 4:37 (1954). 6) de Flines, J., J. Am. Chem. Soc. 77 : 1676 (1955). 7) Cowrie, D. B., Bolton, E. T. and Sands, M. K., J. Bact. $62: 63$ (1951). 8) Bessey, E. A., Morphology and Taxonomy of Fungi, 344 (1952). 9) In course of this study, it was reported that E. Chain had carried out the similar investigations. Summary of the 4th International Congress of Biochemistry (Vienna), 1958.

摘

要

藻菌楼, 露子菌類, 担子菌類および不完全菌類の 4 つの綱に属する菌類 29 種について, 硫黄源としてのコ リン硫酸エステルの効用をしらべた。

Aspergillales, Pyrenomycetes および不完全菌類はいずれもコリン硫酸エステルを硫黄源としてよく利 用する。Alternaria tenuis の培養液中にはコリン硫酸エステルの加水分解によつて生じた硫酸イオンがみ られた。

䣲母菌類はコリン硫酸エステルを利用しないものが多い (Saccharomyces, Schizosaccharomyces, Zygosaccharomyces, Candida) が, Hansenula anomala だけがこれを硫黄源としてよく発育した。

藻菌類はコリン硫酸エステルを利用しないものが多い (Rhizopus nigricans, Mucor, Phycomyces, Absidia ) が, Rhizopus oryzae だけがてれを硫黄源として利用し，よい発育を示した。

担子菌類はいずれもコリン硫酸エステルを硫黄源として利用しないが，てれを与えた場合は正常培地にお せるよりも一般によい発育を示した。 